\section{Frimærkehandler og jernbanehistoriker Peer Olav Thomassens Fond}

Fonden, der er stiftet i 1992, har som formål "Videreførsel af forskningen af fortrinsvis dansk trafik - og kommunikationshistorie" og yder støtte til

a anskaffelse af relevant materiale, herunder til den fornødne bevaring, registrering, katalogisering, indbinding, konservering m.v. af det indgåede materiale

b. udarbejdelse af publikationer, først og fremmest trykomkostninger

c studie- og forskningsudgifter, herunder rejsetilskud, og

d tilskud til afholdelse af udstillinger, seminarer, kongresser mv.

Ad a: Støtte til opbygning af private bogsamlinger falder uden for fondens formål.

Ad c: Da fondens midler er af forholdsvis beskeden størrelse, vil det ikke være muligt at yde effektiv støtte til forskning inden for de i formålsparagraffen nævnte områder i form af løn.

Af hensyn til ekspedition af imødekomne ansøgninger, skal disse indeholde oplysning om modtagerens adresse og personnummer. Hvis ansøgeren er en juridisk person, skal man i ansøgningen oplyse SE-nr.

Ansøgninger vedlagt curriculum vitae, eventuel publikationsliste samt anbefaling(er) stiles til Direktør Erland Kolding Nielsen og sendes til

Det Kongelige Bibliotek

Postboks 2149

1016 København $\mathrm{K}$

\section{TELEFON 33930111 \\ TELEFAX 33329846}

så det er biblioteket i hænde senest 15/I I/97 med morgenposten. Uddelingen forventes at finde sted i December 1997. 